\title{
Learner's Pseudo Mental Model On Performing English Speaking Task Ability
}

\author{
Yudi Hari Rayanto \\ rayanto75@gmail.com
}

PGRI Wiranegara University

\begin{abstract}
The purpose of this study is to find out the causes of pseudo mental model occurred on performing English speaking task ability. This research is conducted to the learners of English department in academic year 2018-2019. This research uses questionnaire as the only instrument. The questionnaire was distributed through WA group of learners' English department. 38 learners got a questionnaire but only 28 learners who returned the questionnaire to the researcher. The questionnaire consists of 17 items. This research uses descriptive qualitative whereas the researcher analyzes and describes the questionnaire distributed and returned from learners of English department. Base on the data gained, the result shows that although learners have high motivation on learning English speaking subject, that is 96\%, pseudo mental model (nervous, afraid, and less confident)on performing English speaking task ability still occurred. Besides that, it also occurs not only because of learners had problems in language component skills, that is $75 \%$, though in fact in specific problems occurred $57 \%$ (problems are not similar) but also in mental model $67 \%$ though preparation is prepared well $92 \%, 78 \%$ before conducting and $71 \%$ during performing, and the frequency of "always " being nervous, afraid and less confident is $64 \%$. Moreover, $92 \%$ learners are trying to reduce of having pseudo mental model (afraid, nervous, lack confident).
\end{abstract}

Keywords: Mental, learning, English speaking

\section{INTRODUCTION}

Human beings as unique creature have much ability which is given down from supreme creator. Their ability for adapting and adopting is not similar one another. Indeed, they have their own uniqueness. As stated by Djiwandono (2008) that each individual as the learner has uniqueness on grasping or understanding the material given. The impact of this uniqueness occurs on the strategy and method on how human solve some trending issues or problems are also unique and different. It indicates that human has different capacities and abilities. The ability of human on facing and solving the problems smoothly are affected by many factors, such as knowledge, experience and mental. 
Mental is an abstract thing. It cannot be seen vividly but it can be felt by human when represent in front of the public. Psychologically, mental affects every human on overcoming the problems occurred. Mental is derived from the internal of humans themselves. Mental is not gaining from reading a book or imitating something from environment. Mental has to be constructed internally by human for making the mental of the model can be much stronger and stronger. In other words, obtaining a strong mental model needs an extra afford and practice all of the time. Ifenthale, Pirnary-Dummer, Spector,(2008) states that a mental model is a cognitive psychological construction and cannot be provided from outside as a fact and the same. Mental models are idiosyncratic, accommodative and they mediate between the outside world and subjective knowledge.

Mental model of the model is a model on how the model of learning (learner) prepares his mental on representing and performing the task given by lecturer. Preparing a strong mental model in learning activity is not an easy task not only for lecturers but also for learners. Commonly, human has a feeling of being lack of conviction, confidence, nervous or and afraid on facing something, especially when it should revealed in front of public. These feelings are called pseudo. Pseudo is a feeling of being doubt on acting and determining something. Being doubt, afraid and nervous often occurs to everyone when they have to do something. Everyone will get nervous when they must perform something. Indeed, it will cause the result of action lack of satisfying. Constructing strong mental model is a must to be done though it needs an extra energy and time for revealing the model's confident and reduced of being nervous and afraid. However, the pseudo mental model should be decreased slowly existed in learners when they have learning activity.

Learning activity is a process of gaining new knowledge. This process involves two important components, they are lecturer and learner. Both of them should work together to make the learning activity runs smoothly. Learning occurs when people actively construct meaningful mental representations from presented information, such as coherent mental models that represent and communicate subjective experiences, ideas, thoughts, and feelings, Mayer et al (1999).Lecturer should be aware that learners have different learning style on adapting and adopting knowledge. Learning styles are personal characteristics that make characteristics of learning effective for some students and not useful for others, Wahyuddin (2016).However, this learning style has an important role in succeeding the learners' achievement. Moreover, the cooperation and collaboration between lecturer and learners in learning activity should be linked earlier for obtaining a meaningful learning. All collaborative learning theory contends that human interaction is a vital ingredient of human learning, Kruse and Keil, (2002).

Learning English speaking subjects can be categorized as a hard thing to be done by lecturer and learner. English speaking subjects in English department differs from other subjects. English speaking must be practiced orally. Practicing English speaking needs a strong mental model because it is not only speaking up but also there are many aspects must be mastered, such as grammar, vocabulary, fluency, accuracy and intonation. These aspects indeed influence the speaker in exploring and delivering the message. They are integrated indeed; lacking grammar influences the meaning, having a little vocabulary affects the speakers' fluency, mispronouncing a proper word obviously influence speaker's intonation. It cannot be imagined if learners are not mastering in all aspects of speaking ability. The complexity of problems in this case occurs. Surely, there are many problems faced by learners on mastering English speaking ability. Besides that, learners must practice and perform the English speaking task ability in front of the class. A mental model (weak or strong) is tested in this activity. 
This research is conducted at PGRI WIRANEGARA University in English department program in academic year 2018-2019. These university learners have already in fourth semester. It means that they already not only gained English speaking subjects 2 years but also other aspects of language components. Therefore, researcher reveals the problem of the research on what causes of pseudo mental model occurred on performing English speaking task ability.

\title{
METHOD
}

The research design of this research is a descriptive qualitative study. The researcher takes university learners from English department at PGRI WIRANEGARA as the subjects of the research. These learners are coming from the fourth semester. The total of the learners are 38, 7 males and the rest are females. For gaining the data, the researcher uses questionnaire. The questionnaire consists of 17 items. This is taken because the researcher is not able to meet the learners face to face during the pandemic of COVID-19. The Questionnaire that has been collected is checked then analyzed. After the data have been collected through questionnaires, the researcher then selected, simplified, and organized the data, then reduced them. It was done to make it easier for the researcher to understand, interpret and make sense out of the collected data. The data gained are analyzed and counted by using the pattern:

\author{
$\mathrm{F}=\frac{\mathrm{N}}{\mathrm{T}} \mathrm{X} 100 \%$ \\ F: The frequency \\ $\mathrm{N}$ : The count respondent \\ T: The total respondent
}

\section{FINDINGS}

As stated earlier, questionnaire is the only instrument used in this research. Moreover, the finding of this research is based on the data gained through the instrument used.

The questionnaire was distributed to 38 Learners University in English Department. The feedback which was from learners was 28 . Unfortunately, there were 10 learners did not respond or gave feedback of questionnaire given.

The questionnaire started with a simple question which was led to learner's likeness of English speaking subjects. Simply, all learners stated that they liked English speaking subjects. This question was raised up for convincing the researcher's conviction that not all learners like English speaking subjects was not true. Likewise, the researcher was afraid there were two or more did not like English speaking subjects. Although, all learners like English speaking subjects, in fact there were 13 learners (46\%) did not start practicing English speaking since elementary school. It was supposed to be started whereas English subjects were started from Elementary school based on the curriculum implemented, that was KTSP. Learning English Speaking subjects is difficult. Mostly, learners were difficult on learning English speaking subjects. It was proven from the questionnaire obtained. There were 21 learners (75\%) had difficulties on learning English speaking subjects. Oddly, from 13 learners who did not practice English speaking subject from Elementary school, there was only 1 learner who did not have difficult on learning English speaking that is learner number 21. From the problems revealed in the questionnaire, the vocabulary problem occurred in 24 learners (85\%), 25 learners (89\%) in 
pronunciation problem, 23 learners' problem (82\%) in grammar, problem in accuracy was 22 learners (78\%), and 22 learners had problems in fluency (78\%). From 7 learners (see table) who did not have difficulties on learning English speaking subject, there were 3 learners had problem in vocabulary, they were number 3,4 and 8 , problem in pronunciation 5 learners, they were number 3,7,8,19, and 21, problem in grammar was 3 learners, they were number 3,7, and 16, there were 4 learners had problem in accuracy, and problem in fluency were 3 learners, they were number 3,4, and 8 .

Every learner must have their motivation on learning English speaking subjects. Therefore, for measuring learners' motivation on learning English speaking subjects, this research only measures high, and standard. Both were taken because, it was impossible if learners had low motivation, second they all were from English department. Base on the data gained, the researcher found that there was only 1 student who did not have high motivation. He addressed himself in standard motivation.

Performing English speaking subjects in front of public needs strong mental. Based on the data obtained, this research found that 19 learners (67\%) had mental problem. Moreover, learners must prepare their preparation well before conducting or performing the English speaking subjects. There were 26 learners $(92 \%)$ stated that they needed preparation. There were 2 learners who stated that they did not need preparation, they were number 1 , and 12 . Although, they already prepared or did not before performing the English speaking subject in front of the public, they still had pre-problem. The 2 learners who did not have to prepare had pre (before) and main (during) problems. Meanwhile, the learners who needed to prepare, there were 6 who stated did not have problem in pre performing problem, they were number 3,7,16, 21, 25, and 28. It meant there were 22 learners $(78 \%)$ stated that they had that problem in pre- performing. Unluckily, from 6 learners who did not have pre performing problem, there were 3 learners had problem during performing, they were number 3, 25, and 28. Likewise, from 5 learners who did not have pre performing problem, they were number 4, 8, 9, 26, and 27, they in fact had problem during performing English speaking subject. Besides that there were 3 learners who did not have problem in pre (before performing) and main (during performing), they were number 8,16 , and 2. It meant there were 20 learners $(71 \%)$ had problem during performing English speaking subjects.

Performing English speaking task ability in front of the public (friends/class) sometimes becomes a nightmare for all learners. They needed to prepare everything to make their performance becomes excellent. Unavoidable, becoming nervous could occur to every learner. To measure the frequency of being nervous, the researcher used adverbial frequent, they were always, and seldom. Based on the data gained, this research found that there were $18(64 \%)$ learners had frequency always, and 10 learners (36\%) were seldom. From 7 learners who did not have difficulties on learning English speaking subjects, there were 4 learners had frequency "always" of being nervous, they were number 4,8,16, and 19. Meanwhile, the language skill problems (vocabulary, pronunciation, grammar, accuracy and fluency) which did not occur in number 4,7,8, 10,11,13,14,15,16, 19,21, and 25 (not all learners got similar problems, see table),in fact, number 4,8,11,13,14,15, 16, and 19 had frequency "always" of being nervous. Likewise, from the learners who had mostly high motivation on learning English speaking subjects (1 learner in standard), 18 learners were in frequency "always" of being nervous. Moreover, the effort for reducing of being nervous of performing English speaking task subject if front of public should be done. From the data gained, 26 learners had an effort to reduce of being nervous (see table). There were 2 learners who did not have an effort to reduce it, they 
were number 3 and 10. Number 3 did not have problems at all in all language skills, meanwhile number 10 had problem only in accuracy.

See the table below:

\begin{tabular}{|c|c|c|c|c|c|c|c|c|c|c|c|c|c|c|c|c|c|}
\hline \multirow[t]{2}{*}{$\bar{L}$} & \multicolumn{17}{|c|}{ Questionnaire items number } \\
\hline & 1 & 2 & 3 & 4 & 5 & 6 & 7 & 8 & 9 & 10 & 11 & 12 & 13 & 14 & 15 & 16 & 17 \\
\hline 1 & $\mathrm{Y}$ & $\mathrm{n}$ & $\mathrm{y}$ & $\mathrm{y}$ & $\mathrm{y}$ & $\mathrm{y}$ & $Y$ & $\mathrm{y}$ & $\mathrm{n}$ & $\mathrm{y}$ & $\mathrm{y}$ & $\mathrm{n}$ & $\mathrm{y}$ & $\mathrm{y}$ & $\mathrm{y}$ & $\mathrm{n}$ & $\mathrm{y}$ \\
\hline 2 & $\mathrm{Y}$ & $\mathrm{y}$ & $\mathrm{y}$ & $\mathrm{y}$ & $\mathrm{y}$ & $\mathrm{y}$ & $Y$ & $\mathrm{y}$ & $\mathrm{y}$ & $\mathrm{n}$ & $\mathrm{y}$ & $\mathrm{y}$ & $\mathrm{y}$ & $\mathrm{y}$ & $\mathrm{y}$ & $\mathrm{n}$ & $\mathrm{y}$ \\
\hline 3 & $\mathrm{y}$ & $\mathrm{y}$ & $\mathrm{n}$ & $\mathrm{y}$ & $\mathrm{y}$ & $\mathrm{y}$ & $\mathrm{y}$ & $\mathrm{y}$ & $\mathrm{y}$ & $\mathrm{n}$ & $\mathrm{n}$ & $\mathrm{y}$ & $\mathrm{n}$ & $\mathrm{y}$ & $\mathrm{n}$ & $\mathrm{y}$ & $\mathrm{n}$ \\
\hline 4 & $\mathrm{y}$ & $\mathrm{y}$ & $\mathrm{n}$ & $\mathrm{y}$ & $\mathrm{n}$ & $\mathrm{y}$ & $\mathrm{y}$ & $\mathrm{y}$ & $\mathrm{y}$ & $\mathrm{n}$ & $\mathrm{n}$ & $\mathrm{y}$ & $\mathrm{y}$ & $\mathrm{n}$ & $\mathrm{y}$ & $\mathrm{y}$ & $\mathrm{y}$ \\
\hline 5 & $\mathrm{y}$ & $\mathrm{y}$ & $\mathrm{y}$ & $\mathrm{y}$ & $\mathrm{y}$ & $\mathrm{y}$ & $\mathrm{y}$ & $\mathrm{y}$ & $\mathrm{y}$ & $\mathrm{n}$ & $\mathrm{y}$ & $\mathrm{y}$ & $\mathrm{y}$ & $\mathrm{y}$ & $\mathrm{y}$ & $\mathrm{n}$ & $\mathrm{y}$ \\
\hline 6 & $\mathrm{y}$ & $\mathrm{n}$ & $\mathrm{y}$ & $\mathrm{y}$ & $\mathrm{y}$ & $\mathrm{y}$ & $\mathrm{y}$ & $\mathrm{y}$ & $\mathrm{y}$ & $\mathrm{n}$ & $\mathrm{y}$ & $\mathrm{y}$ & $\mathrm{y}$ & $\mathrm{y}$ & $\mathrm{y}$ & $\mathrm{n}$ & $\mathrm{y}$ \\
\hline 7 & $\mathrm{y}$ & $\mathrm{y}$ & $\mathrm{n}$ & $\mathrm{n}$ & $\mathrm{y}$ & $\mathrm{y}$ & $\mathrm{n}$ & $\mathrm{n}$ & $\mathrm{y}$ & $\mathrm{n}$ & $\mathrm{n}$ & $\mathrm{y}$ & $\mathrm{n}$ & $\mathrm{n}$ & $\mathrm{n}$ & $\mathrm{y}$ & $\mathrm{y}$ \\
\hline 8 & $\mathrm{y}$ & $\mathrm{y}$ & $\mathrm{n}$ & $\mathrm{y}$ & $\mathrm{y}$ & $\mathrm{n}$ & $\mathrm{n}$ & $\mathrm{y}$ & $\mathrm{y}$ & $\mathrm{n}$ & $\mathrm{n}$ & $\mathrm{y}$ & $\mathrm{y}$ & $\mathrm{n}$ & $\mathrm{y}$ & $\mathrm{n}$ & $\mathrm{y}$ \\
\hline 9 & $\mathrm{y}$ & $\mathrm{n}$ & $\mathrm{y}$ & $\mathrm{y}$ & $\mathrm{y}$ & $\mathrm{y}$ & $\mathrm{y}$ & $\mathrm{y}$ & $y$ & $\mathrm{n}$ & $\mathrm{n}$ & $\mathrm{y}$ & $\mathrm{y}$ & $\mathrm{n}$ & $\mathrm{n}$ & $y$ & $\mathrm{y}$ \\
\hline 10 & $\mathrm{y}$ & $\mathrm{n}$ & $\mathrm{y}$ & $\mathrm{y}$ & $\mathrm{y}$ & $\mathrm{y}$ & $\mathrm{n}$ & $\mathrm{y}$ & $\mathrm{y}$ & $\mathrm{n}$ & $\mathrm{n}$ & $\mathrm{y}$ & $\mathrm{y}$ & $\mathrm{y}$ & $\mathrm{n}$ & $\mathrm{y}$ & $\mathrm{n}$ \\
\hline 11 & $\mathrm{y}$ & $\mathrm{n}$ & $\mathrm{y}$ & $\mathrm{y}$ & $\mathrm{y}$ & $\mathrm{y}$ & $\mathrm{y}$ & $\mathrm{n}$ & $\mathrm{y}$ & $\mathrm{n}$ & $\mathrm{y}$ & $\mathrm{y}$ & $\mathrm{y}$ & $\mathrm{y}$ & $\mathrm{y}$ & $\mathrm{y}$ & $\mathrm{y}$ \\
\hline 12 & $\mathrm{y}$ & $\mathrm{n}$ & $\mathrm{y}$ & $\mathrm{y}$ & $\mathrm{y}$ & $\mathrm{y}$ & $\mathrm{y}$ & $y$ & $y$ & $\mathrm{n}$ & $\mathrm{y}$ & $\mathrm{n}$ & $\mathrm{y}$ & $\mathrm{y}$ & $\mathrm{y}$ & $\mathrm{n}$ & $\mathrm{y}$ \\
\hline 13 & $\mathrm{y}$ & $\mathrm{y}$ & $\mathrm{y}$ & $\mathrm{y}$ & $\mathrm{y}$ & $\mathrm{y}$ & $\mathrm{y}$ & $\mathrm{n}$ & $\mathrm{y}$ & $\mathrm{n}$ & $\mathrm{y}$ & $\mathrm{y}$ & $\mathrm{y}$ & $\mathrm{y}$ & $\mathrm{y}$ & $\mathrm{n}$ & $\mathrm{y}$ \\
\hline 14 & $\mathrm{y}$ & $\mathrm{y}$ & $\mathrm{y}$ & $\mathrm{y}$ & $\mathrm{y}$ & $\mathrm{n}$ & $\mathrm{n}$ & $\mathrm{y}$ & $\mathrm{y}$ & $\mathrm{n}$ & $\mathrm{y}$ & $\mathrm{y}$ & $\mathrm{y}$ & $\mathrm{y}$ & $\mathrm{y}$ & $\mathrm{n}$ & $\mathrm{y}$ \\
\hline 15 & $\mathrm{y}$ & $\mathrm{n}$ & $\mathrm{y}$ & $\mathrm{y}$ & $\mathrm{y}$ & $\mathrm{n}$ & $\mathrm{y}$ & $\mathrm{y}$ & $\mathrm{y}$ & $\mathrm{n}$ & $\mathrm{y}$ & $\mathrm{y}$ & $\mathrm{y}$ & $\mathrm{y}$ & $\mathrm{y}$ & $\mathrm{n}$ & $\mathrm{y}$ \\
\hline 16 & $\mathrm{y}$ & $\mathrm{y}$ & $\mathrm{n}$ & $\mathrm{n}$ & $\mathrm{n}$ & $\mathrm{y}$ & $\mathrm{y}$ & $\mathrm{n}$ & $\mathrm{y}$ & $\mathrm{n}$ & $\mathrm{y}$ & $\mathrm{y}$ & $\mathrm{n}$ & $\mathrm{n}$ & $\mathrm{y}$ & $\mathrm{n}$ & $\mathrm{y}$ \\
\hline 17 & $\mathrm{y}$ & $\mathrm{n}$ & $\mathrm{y}$ & $\mathrm{y}$ & $\mathrm{y}$ & $\mathrm{y}$ & $\mathrm{y}$ & $\mathrm{y}$ & $y$ & $\mathrm{n}$ & $\mathrm{y}$ & $\mathrm{y}$ & $\mathrm{y}$ & $\mathrm{y}$ & $\mathrm{n}$ & $\mathrm{y}$ & $\mathrm{y}$ \\
\hline 18 & $\mathrm{y}$ & $\mathrm{y}$ & $\mathrm{y}$ & $\mathrm{y}$ & $\mathrm{y}$ & $\mathrm{y}$ & $\mathrm{y}$ & $y$ & $y$ & $\mathrm{n}$ & $\mathrm{y}$ & $\mathrm{y}$ & $\mathrm{y}$ & $\mathrm{y}$ & $\mathrm{y}$ & $\mathrm{n}$ & $\mathrm{y}$ \\
\hline 19 & $\mathrm{y}$ & $y$ & $\mathrm{n}$ & $\mathrm{n}$ & $\mathrm{y}$ & $\mathrm{n}$ & $\mathrm{n}$ & $\mathrm{n}$ & $\mathrm{y}$ & $\mathrm{n}$ & $\mathrm{y}$ & $\mathrm{y}$ & $\mathrm{y}$ & $\mathrm{y}$ & $\mathrm{y}$ & $\mathrm{n}$ & $\mathrm{y}$ \\
\hline 20 & $\mathrm{y}$ & $\mathrm{n}$ & $\mathrm{y}$ & $\mathrm{y}$ & $\mathrm{y}$ & $\mathrm{y}$ & $\mathrm{y}$ & $\mathrm{y}$ & $\mathrm{y}$ & $\mathrm{n}$ & $\mathrm{n}$ & $\mathrm{y}$ & $\mathrm{y}$ & $\mathrm{y}$ & $\mathrm{y}$ & $\mathrm{n}$ & $\mathrm{y}$ \\
\hline 21 & $\mathrm{y}$ & $\mathrm{n}$ & $\mathrm{n}$ & $\mathrm{n}$ & $\mathrm{y}$ & $\mathrm{n}$ & $\mathrm{y}$ & $\mathrm{n}$ & $\mathrm{y}$ & $\mathrm{n}$ & $\mathrm{n}$ & $\mathrm{y}$ & $\mathrm{n}$ & $\mathrm{n}$ & $\mathrm{n}$ & $\mathrm{y}$ & $\mathrm{y}$ \\
\hline
\end{tabular}




\begin{tabular}{|l|l|l|l|l|l|l|l|l|l|l|l|l|l|l|l|l|l|}
\hline 22 & y & y & y & y & y & y & y & y & y & n & y & y & y & y & y & n & y \\
\hline 23 & y & n & y & y & y & y & y & y & y & n & y & y & y & y & y & n & y \\
\hline 24 & y & n & y & y & y & y & y & y & y & n & y & y & y & y & y & n & y \\
\hline 25 & y & n & y & y & n & y & n & y & y & n & y & y & n & y & n & n & y \\
\hline 26 & y & y & y & y & y & y & y & y & y & n & y & y & y & n & n & y & y \\
\hline 28 & y & y & y & y & y & y & y & y & y & n & y & y & y & n & n & n & y \\
\hline
\end{tabular}

Note: y (yes)

$\mathrm{N}($ no)

\section{DISCUSSION}

Learning English speaking subjects for Learners at University in English department cannot be avoided. It is a compulsory subject which must be taken starting first level until fourth level. Surely, all learners who are in English department are supposed to have high motivation on learning not only for English speaking subject but also in every subject which are already determined by curriculum. Having high motivation is granted as one of the indicator of being success on achieving high achievement on learning. Sherman et al (2005) states that the lack of interest is generally the number one reason that students give for not learning to mastery level. In fact, having high motivation does not ensure optimally if the learners do not urge themselves to reach the quality of themselves There are still many aspects on learning should be gained. It occurs on learning English speaking. There are many aspects which must be grasped by learners on learning English speaking subject. The aspects of being expert on learning English subject, learners have to have five aspects, they are having much vocabularies, good in grammar, pronunciation, fluency and accuracy. In fact, although these aspects have already been in all learners, they still have other problem, that is mental.

Mental model of learners must be trained well. Constructing a mental model is the basis for learning a new concept because something can be learnt, it has to be understood, Seel (2003); Hilgard \& bower (1975), and therefore a student first has to construct a mental model. A habit of practicing English speaking must be done every day, every time and everywhere. Learners' English speaking ability must be practiced all the time, otherwise, learners will automatically will never be accustomed to using English speaking subjects well any longer in front of the public. In other words, learners will be recognized of having pseudo mental model. Learners will be nervous, afraid and lack of confident all the times when they have to perform English speaking subject in front of the class. One of the indicators or factors of having pseudo mental model occurs when learners do not have a habit of conversation. As stated by Nur (2013) that the concept of conditioning should be implemented well in order to get the result optimally. Therefore, learners have to force themselves to implement orally their English speaking ability all the times. 


\section{CONCLUSION}

Pseudo mental model of learners in performing English speaking task ability occurs when learners never implement their ability in front of the class or public. The ability of learners on language components ability and have high motivation does not guarantee that learners can perform well. Learners still have pseudo mental model on performing English speaking task ability in front of the public. Therefore, for reducing the pseudo mental model of learners do not only by improving the language components skill but also the mental model of learners should be trained well by giving wide space for learners to practice English speaking ability in front of the class every times and in daily activity.

\section{REFERENCES}

Djiwandono, G. (2010). Nowadays English Teaching-Promoting Self-Directed Learning. Kolita Journal. Jakarta: Kolita Press

Hilgard, E.R., \& Bower,G.H. (1975).Theories of Learning .Englewood Cliffs; N.J: Prentice Hall

Ifenthaler, Dirk., Pirnary-Dummer., Spector, J.M. (2008). Understanding Models for Learning and Instruction. In Blumschein, Patrick; Model Centered Learning and Instructional Design, Albert-Ludwigs-university, Freiburg, Germany.

Kruse, K., and Keil, J. (2002). Technology Based Training: The Art of Science of Design, development and delivery. San Francisco: Jossey Bass Pfeiffer

Mayer, R.E., Moreno, R., Boire, M., \& Vagge, S. (1999). Maximizing constructivist learning from multimedia communication by minimizing cognitive load. Journal of Educational Psychology, 91 (4),638-643

Nur, Fitriani. (2013). 'The causative factors of pseudo-thinking in solving questions of linear function tightness involve mutal value based on students" cognitive style. Journal of mathematics and learning Vol.1 No.1 Desember (2013):69-91

Seel, N.M. (2003). Stochastic model of change. Unpublished manuscript

Sherman, T., \& Kurshan, B.(2005). Constructing learning: Using technology to support teaching for understanding. Learning \& Leading with technology,32, 10-13

Wahyuddin, W.(2016). "Gaya Belajar Mahasiswa”Al Qalam, vol. 33, no. 1, pp. 105-120 